\title{
Food safety investments factors in the Italian meat sector: conceptual framework and empirical evidence
}

\author{
Andrea MarchinI*, Bianca Polenzani* ${ }^{\star}$, Chiara Riganelli**, \\ Gaetano Martino*
}

DOI: $10.30682 / \mathrm{nm} 2002 \mathrm{~d}$

JEL codes: Q13

\begin{abstract}
The paper investigates how food safety investment decisions are affected on the one hand by laws and on the other by firm's economic and organizational drivers. The paper shares findings from an empirical study that considers investments in HACCP, Certification, and Traceability in the Italian meat sector. The main finding of the study is that the allocation of the decision rights to invest in food safety explains the patterns of investment decisions observed. The conclusion is that regulatory interventions are more effective if there is a private possibility to allocate investment decision rights with respect to the distribution of information between private and public agents and the degree of uncertainty. The study contributes to the analysis of the allocation of the decision rights in the organization of value chain. Under this innovative view, it empirically shows how regulation and freedom of contract act as drivers of food safety investments. The research is particularly interesting in its policy implication: information regarding the role of these collective bodies will become relevant in the near future in the context of expected changes in the EU's agricultural policy.
\end{abstract}

Keywords: Food safety, Decision rights, Organization, Regulation.

\section{Introduction}

Food safety directly pertains to food availability as a basic characteristic of the food (McMichael et al., 2007): for human health and then environmental sustainability, for social concerns central to sustainable strategy building (Beske $e t$ $a l ., 2008$ ), and for economic sustainability (Martino, Perugini, 2006; Loader and Hobbs, 1999).

This study considers three basic organizational systems that have been developed to achieve food safety objectives Hazard anal- ysis critical control point system (HACCP), Certification and Traceability as they support the main strategies designed by farms and food companies in the field of food safety (Martino and Bovorovà, 2014).

HACCP is studied with regard to management issues and the associated implementation difficulties (Wilcock et al., 2011). Heyder et al. (2012) showed that the costs caused by the management of traceability systems negatively influence the choice to adopt them, whereas the intention to invest has a positive effect of the

\footnotetext{
* Department of Agriculture, Food and Environmental Sciences, University of Perugia, Perugia, Italy.

** Department of Economics, University of Perugia, Perugia, Italy.

Corresponding author: chiara.riganelli@gmail.com
} 
adoption of the adequate technology. Banterle and Stranieri (2008) investigated the voluntary traceability systems and found they increase asset specificity in inter-firm relationships. It is usually recognized the critical importance of voluntary and mandatory certification systems within safety strategies (Crespi and Marette, 2001; Fares and Rouviere, 2010; Malorgio et al., 2016). This study aims at contributing to this literature, focusing on the role of the decentralization of the decision rights to invest in order to implement food safety strategies. We focused on the negotiation of the governance structures between transacting parties in Italian meat value chains, recognizing the importance of safety investments to meet both the law and market requirements. This paper is organized as follows. In the second paragraph we introduce the conceptual framework and propose two research questions: a) is the decentralization of the decision rights to invest, in order to implement the safety strategies, associated with the investment decisions in the three food safety systems? and b) what is the relative importance of legal decisions and of the freedom of contract in the investment decisions? We firstly address these questions by drawing a conceptual framework from transaction Cost Economics (Ménard, 2018; 2013). Then we illustrate the empirical analysis conducted at the firm level in the Italian meat sector (paragraph 3). The empirical results are presented and discussed in par. 4, while the final paragraph is dedicated to conclusions.

\section{Conceptual framework}

\subsection{Investments in food safety: literature review}

The implementation of safety-oriented activities is associated with monitoring and controlling - while signaling to consumers and chain partners - the degree of safety of the products delivered is a critical strategic tool (Elbasha, Riggs, 2003). Private individual and collective investments are required to support the safety-oriented activities (Lupien, 2005), allowing producers and traders to cope with both technical and behavioural risks (Dosman et al., 2001). Food chains agents should mainly invest in physical and human resources as well as should organize production processes and control activities in order to implement the safety systems (Quetier et al., 2005).

The HACCP system (see Reg. (EC) 852/2004, Reg. (EC) 853/2004 and Reg. (EC) 854/2004) provides a systematic approach to achieve the reduction of foodborne illness (Tompkin, 1990). It is a methodology, which consents to identify and evaluate the errors that are involved in food preparation. It focuses on risk management, and it can be linked to operational management and food chain safety assurance (Tian, 2017). Especially at the level of primary production, it is able to prevent most important microbiological contamination (Gil et al., 2015). It may minimize the probability of food scandals and maximize the company market share to contribute to food quality (Psomas and Kafetzopoulos, 2015). The HACCP plan should be customized by each firm, and should be updated as future changes are made in the process or the establishment. Economic incentives and the compliance with the law are the main motivations to implement HACCP (Karaman et al., 2012; Wilcock et al., 2011).

Certifications are synonymous with compliance with a pre-defined standard related to a business, a product, a service or a management system. The standard can be public (stated by the law), private or a hybrid (Rott, 2019). Crespi and Marette (2001) analyzed alternative certification systems and showed that voluntary and mandatory arrangements perform differently depending on the structure of the market. Certification may cover various fields (product name protection, environment sustainability, organic production, etc.). Moreover food safety standard certification plays a crucial role in the food safety management system, with benefits in terms of control and assurance practices (Nanyunja et al., 2015). Certification systems based on audits are the most efficient way to obtain high levels of food safety management, implementing the control forms inside the company (Jacxsens et al., 2015).

Traceability is defined as: "the ability to trace and follow a food, feed, food-producing animal or substance intended to be, or expected to be incor- 
porated into a food or feed, through all stages of production, processing and distribution" (European Commission, 2002). Like HACCP, traceability is mandatory and is the key to enforce food safety regulation and controls (Leal et al., 2015). Traceability is an essential quality management subsystem, and can lead to the optimization of data collection systems, production, product safety, and market advantages (Regattieri et al., 2007). This obligation can be achieved through various systems such as alphanumerical codes, bar codes, RFID (Tian, 2017; Galvez et al., 2018).

There are three main types of investment necessary to implement HACCP, Certification and Traceability: physical resources, human resources and additional costs. Examples of physical resources are laboratories for the analysis of raw material and products (HACCP, Certification) or computer resources necessary to store and analyze data (all the three systems). The development and the use of specific human skills and competences are requested for all the three systems, while the procedures necessary for managing all the three systems usually imposes significant additional costs. While these types of investments are needed to implement and manage the three systems, each system requires specific investment (e.g., specific laboratory). This study does not account for such a detail, but only considers the three main type of investment mentioned.

\subsection{Modelling the investment decision in food safety}

\subsubsection{Interdependence, information asymme- try and uncertainty in safe food supply}

In organizing the food safety supply, a coordination issue arises because of the fact that, while each agent has to implement the best technology available, the final safety level of the product will depend upon the choices of all the chain agents (Martino and Perugini, 2006). This is because the source of accidents - chemical, physical, microbiological, etc. - may occur at any stage of the system and because remedies and precautions intentionally implemented may fail due to technological flaws or human errors.
Moreover, most safety characteristics are credence in nature, therefore an information asymmetry arises among the chain partners. Information asymmetry may also entail a reduction in the quality standards supplied and may require accurate identification of responsibilities and chain leadership. Accordingly, the supply of safe food has to be held as an outcome of the choice of adequate governance structures organizing the transaction along the chain (Martino and Perugini, 2006; Hammoudi et al., 2009).

The transacting parties seek to align the attributes of the transaction - asset specificity, uncertainty and frequency - to the characteristics of the governance structure (Williamson, 1985). Technological uncertainties are inherently associated with safety, as the chain organization of the production process may fail to cope with technological unforeseen contingencies and human mistakes (Lupien, 2005). Due to the inherent information asymmetry and the attributes of transactions, the agents face a behavioural uncertainty (Hobbs, 2004) which may strongly influence the level of safety of the final product. In general, due to the critical influence of the interdependence patterns and to information asymmetry, specific contractual hazards may arise because of difficulties in monitoring the behaviour of the transaction counterparties. In sum, on the one hand, effective food safety provision systems (HACCP, Certification, Traceability) are thought to cope with both coordination and information issues; on the other hand, technological and behavioural uncertainty also require the agents to invest resources in food safety systems intended to channel information along the chain, and to favour coordination among the agents (Martino and Perugini, 2006; Hobbs, 2004; Dosman et al., 2001). Moreover, the necessity of coordinating tends to increase the interdependence of the parties along the chain and in each specific transaction (Ménard, 2013; 2018). In the following we first discuss the necessity to regulate the field of food safety and then focus on the decentralization of the decision rights as a critical step in choosing the governance structure, which in turn allows the agents to effectively coordinate themselves. 


\subsubsection{The necessity to regulate}

Coase (1959) stated that one of the purposes of the legal system is to establish a clear delimitation of rights on the basis of which the transfer and the recombination of the rights can take place through the market. This delimitation is a necessary prelude to market transactions, but the final result is independent of the legal decision (Coase, 1959, p. 27). One of the classes of cases in which a specific regulation is preferable, is that in which the transfer of rights would require that the market transaction be carried out among many participants. In such cases the negotiation may be extremely costly and may make the transaction impossible; moreover, in such a situation it could also be impossible for a court to enforce the rights (Coase, 1959, p. 29). The coordination of all the agents for safety purposes is one of such cases, and therefore regulation has to be intended as preferable. Accordingly, regulations set by dedicated legal decisions are an "essential prelude to market transaction" (Coase, 1959, p. 27). More precisely, the regulations state what people must or must not do. When this is done, the law firstly determines the location of the economic activities, method of production and so on (Coase, 1959, p. 29). The law can then be interpreted as a cause motivating the decision on investments aimed at guaranteeing the safety degree of the food.

\subsubsection{Modelling the choice of the govern- ance structure}

Ménard (2018) characterizes the modes of governance in terms of decentralization and centralization of decision and property rights (see Figure 1). The more strategic are the assets, the more contractual parties tend to centralize property and decision rights over them (Ménard, 2018 , p. 150). Consider the level $I_{0}$ of incentive to invest: this may imply, for example, investments in HACCP laboratories to be built on by both the two transacting parties. The Figure 1 indicates that this case corresponds to an intermediate level of resources pooling: actually, while the HACCP system is a duty set by law, the laboratories functions could be designed taking into account the characteristics of the production processes managed by the transacting parties. Alternative level of decision rights decentralization could be associated to the level $I_{0}$. A party to this transaction may find efficient to hold the decision right to invest (level $d_{1}$ ). In this case, the two parties will decide separately to invest in laboratories and then the two laboratories will be made by two distinct decision makers (decentralization case: $A_{1}$ ). Alternatively, the party may find convenient to allocate to the counterparty the decision right (level $d_{1}$ ): in this case the two laboratories will be made by through the decision of just one decision maker (centralization case: $\left.A_{0}\right)$. The theory states that it is usually the increasing level of uncertainty which induce the

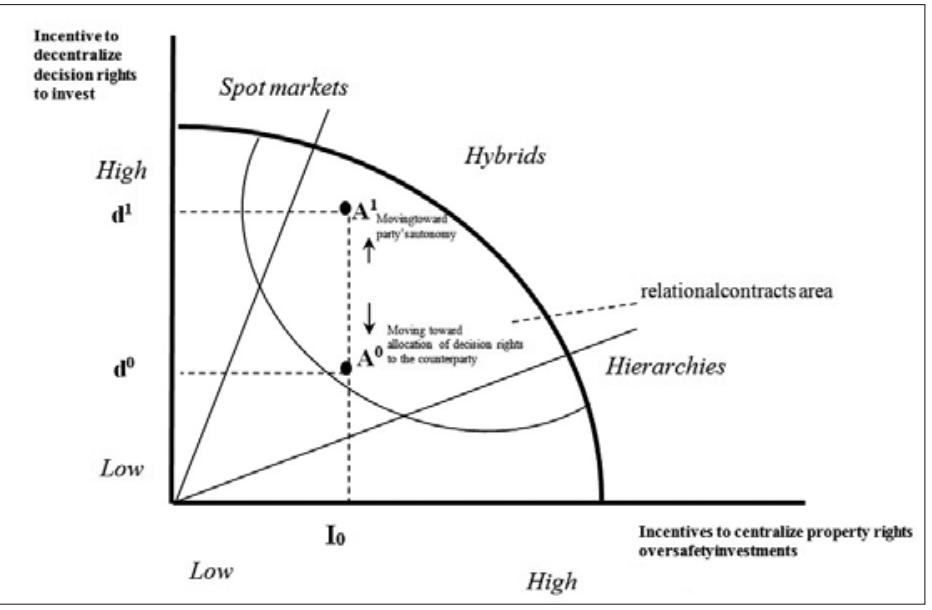

Figure 1 - Governance structure. Source: authors' elaboration on Ménard (2018). 
Figure 2 - Identification of investments drivers.

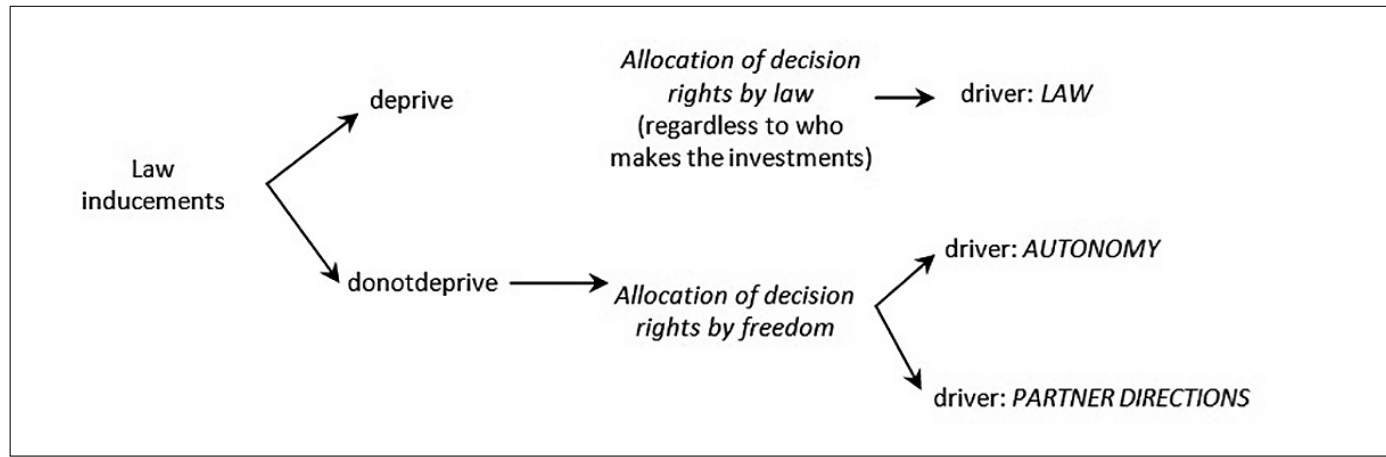

Source: authors'elaboration on Ménard (2018).

parties to adopt a more centralized pattern of the decision making process.

The model connects the decision to invest in food safety to the negotiation over the governance structure and the related allocation of decision rights. As essential prelude of the market transaction (Coase, 1959), we expect that the law influences some investment decisions (i.e. HACCP and Traceability), but we also expect that an interlink may exist with the investment decision channelled by the negotiation between the parties.

The Figure 2 illustrates alternative decentralization level of decision right to invest. First, it may be the case that the agents have not the right to negotiate the allocation of the decision right to invest. This is the case in which the law imposes compulsory investment (e.g. the main part of the resources supporting an HACCP system) and then deprive the parties to decide the allocation of the decision right to invest. The legal system has actually also the purpose to establish a clear delimitation of rights on the basis of which the transfer and the recombination of the rights can take place through the market (Coase, 1959).

In the alternative case the parties can negotiate the allocation of the decision rights on the safety investment. There may be then three cases:

i. a party may find convenient to hold the decision right to invest (case $A_{1}$ );

ii. a party may find a convenient to negotiate the decentralization of the decision rights (case $\left.A_{0}\right)$; iii. a party may find convenient to not invest (if legally admitted).

Theory analyzes the underlying factors inducing the choice of centralizing the decision rights (Ménard, 2013; 2018). To solve the coordination problem tends to increase the bilateral dependency among the parties to a transaction and this in turn may increase the convenience of centralizing. On the other hand, the investments made by a party may have a degree of complementarity with the investments made by the counterparties. For example, the laboratories may gather and store together critical information in a more efficient way if their functions are designed to jointly support the transaction. This confirm that co-specialization and complementarity of investment (Buvik and Grønewald, 2000; Lafontaine and Slade, 2013, pp. 1002 ff.) in connecting the transaction parties.

\subsubsection{Research questions and hypotheses}

Drawing from the previous conceptual framework we introduce the following research questions:

a) Is the allocation of the decision rights to invest in order to implement the safety strategies associated the investment made in the three food safety systems?

b) What is the relative importance of legal decisions and of the freedom of contract as causes of the investment decisions?

We empirically address these research questions by a quantitative analysis of data collected 
by surveying Italian meat firms (par. 3). Italian and European laws first regulated HACCP. Certification systems are generally based on voluntary approaches, which are often driven by bodies regulating international standards (e.g. ISO 9000), and are integrated by labelling laws, which are currently under revision at the European level. Thus, it is expected to follow the main influences of the drivers identified:

\begin{tabular}{|l|c|c|}
\hline & Law & $\begin{array}{c}\text { Freedom of contract } \\
\text { (Freedom-Partner } \\
\text { direction) }\end{array}$ \\
\hline HACCP & + & \\
\hline Certification & & + \\
\hline Traceability & + & \\
\hline
\end{tabular}

HACCP and Traceability are more intensively regulated by the law. However, the additional effects of Freedom and Partner direction on the investment decisions, made within these systems cannot be excluded a priori.

\section{Empirical analysis}

\subsection{Data}

The data were collected by through a postal questionnaire submitted to 2,069 Italian meat companies. The postal addresses were provided by Poste Italiane (the company managing national mail service) and were selected because they were active in the supply of animal products and were engaged in various stages of food chains (i.e., agricultural, processing and trading activities). The unit of observation is the firm. The sample includes firms belonging to all the meat chain stages; therefore, we cannot investigate any effect potentially associated to the stage.

The questionnaire used in the inquiry includes three sections: a) general information about each company, including the date of establishment and the sizes and fields of activity (e.g. production, trade); b) relationships with other enterprises in the chains, with a focus on the type of contract (verbal, written, short term or long term) and the related decision (procurement, selling and duration), with related data that are not pre- sented here but are part of a separate future investigation; and c) the activities undertaken in the field of food safety as the type of system implemented (HACCP, Certification, Traceability or none) and the investments made to support the system that was built (physical resources, human resources, and additional costs). The goal is to answer the following question:

- which of the following investments have you made for those quality and safety systems?

\begin{tabular}{|l|c|c|c|}
\hline & $\begin{array}{c}\text { Physical } \\
\text { resource } \\
\text { (e.g. plant, } \\
\text { storages, } \\
\text { laborato- } \\
\text { ries, equip- } \\
\text { ment) }\end{array}$ & $\begin{array}{c}\text { Human } \\
\text { resources } \\
\text { (e.g. train- } \\
\text { ing, } \text { hiring of } \\
\text { specialized } \\
\text { profession- } \\
\text { als) }\end{array}$ & $\begin{array}{c}\text { Persistent } \\
\text { additional } \\
\text { manage- } \\
\text { ment costs }\end{array}$ \\
\hline HACCP & & & \\
\hline Certification & & & \\
\hline Traceability & & & \\
\hline
\end{tabular}

The answers were treated as dependent variables (see par. 3.3.). Furthermore, the following question was also submitted if the respondent declared they made some of the investments mentioned:

- what was the driver of these decisions?

\begin{tabular}{|l|c|c|c|}
\hline & $\begin{array}{c}\text { Legal } \\
\text { obligation }\end{array}$ & $\begin{array}{c}\text { Free } \\
\text { choice }\end{array}$ & $\begin{array}{c}\text { Partner } \\
\text { requests }\end{array}$ \\
\hline HACCP & & & \\
\hline Certification & & & \\
\hline Traceability & & & \\
\hline
\end{tabular}

The answers were treated as the main independent variables, in association with further information concerning sources of safety information, the implementation of specific hygiene practices and internal safety information management.

In Italy the meat industry (in which the three main supply chains are the beef sector, the pig sector and the poultry sector) yields an economic value on the order of 30 billion euros, which includes both the industry and the livestock farms (ISMEA and ISTAT data, 2016). The majority of Italian livestock farms are located in the 
northern Italy, where there are huge resources available for agriculture (General Census of Agriculture). Considering the number of employees, the beef sector holds the largest number of employees, followed by the pig sector and then the poultry sector.

The composite nature of Italian farms leads to multiple and different farm types, especially along the meat supply chain. This unstructured and variegated panorama makes the organization of production a crucial element, possibly by the integration of the different related production systems (e.g. the milk processing). This integration is also an important factor in quality control. Indeed, in light of recent food scandals, the meat sector shows the need for more efficient forms of control, with benefits for both consumers and producers.

\subsection{Statistical analysis}

\subsubsection{Method}

Each system is associated with one to three responses for each type of investment. Following Agresti and Liu (2001), we managed the response as multiple responses, regardless of the type of investment, and implemented a generalized estimating equations (GEE) model. The estimated models take the following form: ${ }^{1}$

(1) $\mathrm{INV}_{-\mathrm{i}}=\alpha_{0}+\alpha_{1}$ Law $_{-\mathrm{i}}+\alpha_{2}$ Auton $_{-\mathrm{i}}+\alpha_{3}$ Partndir ${ }_{-\mathrm{i}}+\Sigma \alpha_{\mathrm{i}} \mathrm{x}_{\mathrm{ik}}+\varepsilon_{\mathrm{i}}$

where:

INV $i=$ dependent variable, i.e. investment made in the ith systems, with $\mathrm{i}=H A C C P$, Certification, Traceability.

"Law_i", "Auton_i" and "Partndir_i" are the independent variables. The subscript "i" identifies the three types of food safety objective: HACCP system, Certification and Traceability.

$\mathrm{x}_{\mathrm{ik}}=$ beliefs, source of information, control variables: Ndir; Exper; Sales.

In the research systematic expectations regarding the set of xi variables cannot be formulated. Rather, the question regarding the nature of the variables' influence is addressed.
The investment decisions made to comply with the law and those made according to the parties' full freedom of the market may be interlinked. This may happen because the parties recognize the importance of the area of activity identified by the law in order to achieve a high safety performance. For example, the parties may invest in human resources or additional management costs to enhance the HACCP or traceability systems in compliance with the requirements of law. The parties may also set and manage certification standards in addition to the legal obligations. We interpret the interlinkage between compliance with the law and the related potential free decisions of the parties in terms of complementarity. According to Milgrom and Roberts (1990) the activities undertaken by the parties integrating the investments required by the law, with investments driven by the parties' freedom of contract, are expected to enhance the safety performance compared to the situation in which the investments would be separately made. We then test the existence of complementarity between the types of investments mentioned (physical resources, human resources, additional costs) by following the approach designed by Cassiman and Veugelers (2006) and by estimating nine bivariate probit models concerning the three types of investment for the three systems (HACCP, Certification, Traceability). Bivariate probit is a generalization of the probit model. A bivariate probit model includes two probit equations with different dependent variables.

In the bivariate probit model there are two binary dependent variables $Y_{1}$ and $Y_{2}$, so there are two latent variables $\mathrm{Y}^{*}$ and $\mathrm{Y}^{*}{ }_{2}$.

We specified each model by considering all the combinations of the types of investments in the two equations of the model (PR_HACCP-HR_HACCP, PR_HACCP-CO_HACCP, HR_HACCP-CO_HACCP, etc.).

If the residuals of the two equations are correlated (i.e., if the correlation coefficient $\rho$ between them is relatively large and statistically significant), then we conclude that the two investment decisions (e.g. investment in PR_HACCP and

1 The analysis uses a logit link function and the assumption is that the correlations are constant across observations (for details, see Agresti and Liu, 2001). 
investment in HR_HACCP) jointly occur. According to Cassiman and Veugelers (2006), in this case we considered the explanatory variables in each model and compared their statistical significance in the bivariate model with respect to the alternative univariate probit model. We concentrated our attention on the variables accounting for the investment drivers: Law, Freedom and Partnerdir. The complementarity between the types of investments should highlight the significance of some or all of these variables. This is because the variable - for example Law - has an indirect effect on one type of investment (say, HR_HAC$\mathrm{CP}$ ) because of its complementarity with the other type (say, PR_HACCP) (Cassiman and Veugelers, 2006, pp. $71-72$ and pp. 78-79). If there is no evidence for the correlation between the residuals in the bivariate model, we reject the hypothesis of complementarity and of interlinkage among the causes of the investment decisions.

\subsubsection{Independent variables}

The independent variables are primarily the three factors potentially causing the investment decisions: Law, Autonomous decision, Partner direction. We defined these variables in the conceptual framework (par. 2.2.3). Empirical evidence about these factors can be found for example in Trienekens and Zuurbier (2008) who extensively reviewed public and private food standards making clear how the investment factors trigger the standard setting giving raise to complex institutional framework.

Additional costs and the lack of adequate physical conditions ranked highest among the barriers limiting the diffusion of the HACCP system (Karaman et al., 2012). Wilcock et al. (2011, p. 29) identify human resources as necessary requirements for the implementation of an effective food safety system. Heyder et al. (2012) show that the costs generated by the management of traceability systems negatively influence the choice to adopt them, whereas the intention to invest has a positive role in the diffusion of these systems. The necessity of confronting increased costs caused by the adoption of food safety systems has also been emphasized in other studies (Segerson, 1999). In this context, scholars have recognized that human resources, staff skills and training, and information technologies are the most prominent resources sustaining food safety systems. Human resources and additional management costs are expected to be more diffused investments for supporting food safety strategies. Nevertheless, physical resources appear to maintain a prominent role even in the context of technological and management changes (Herath and Henson, 2010; Heyder et al., 2012).

Table 1 - List of variables.

\begin{tabular}{|c|c|c|c|c|c|}
\hline Variable & Symbol & Code & Obs. & Freq. & $S D$ \\
\hline \multicolumn{6}{|l|}{ Type of investments } \\
\hline \multicolumn{6}{|l|}{$\begin{array}{l}\text { Physical Resources (HACCP, Certification, } \\
\text { Traceability) }\end{array}$} \\
\hline • Physical Resource - HACCP & PR_HACCP & 0,1 & 117 & 72 & 0,49 \\
\hline - Physical Resource - Certification & PR_Cert & 0,1 & 117 & 37 & 0,47 \\
\hline • Physical Resource - Traceability & PR_Trace & 0,1 & 117 & 75 & 0,48 \\
\hline $\begin{array}{l}\text { Human Resources (Haccp, Certification, } \\
\text { Traceability) }\end{array}$ & & & & & \\
\hline • Human Resources - HACCP & HU_HACCé & 0,1 & 117 & 40 & 0,48 \\
\hline - Human Resources - Certification & HU_Cert & 0,1 & 117 & 39 & 0,47 \\
\hline • Human Resources - Traceability & HU_Trace & 0,1 & 117 & 31 & 0,44 \\
\hline $\begin{array}{l}\text { Additional Costs (Haccp, Certification, } \\
\text { Traceability) }\end{array}$ & & & & & \\
\hline • Additional Costs - HACCP & CO_Haccp & 0,1 & 117 & 39 & 0,47 \\
\hline -Additional Costs - Cartification & CO_Cert & 0,1 & 117 & 27 & 0,42 \\
\hline -Additional Costs - Traceability & CO_Trace & 0,1 & 117 & 42 & 0,48 \\
\hline
\end{tabular}




\begin{tabular}{|c|c|c|c|c|c|}
\hline Variable & Symbol & Code & Obs. & Freq. & $S D$ \\
\hline \multicolumn{6}{|l|}{ Investment factors } \\
\hline \multicolumn{6}{|l|}{ Legal dulie } \\
\hline • Legal duties - HACCP & Law_HACCP & 0,1 & 117 & 78 & 0,47 \\
\hline - Legal duties - Certification & Law_Cert & 0,1 & 117 & 32 & 0,45 \\
\hline - Legal duties - Traceability & Law_Trace & 0,1 & 117 & 49 & 0,5 \\
\hline \multicolumn{6}{|l|}{ Autonomous decision } \\
\hline •Autonomous decision - HACCP & Auton_HACCP & 0,1 & 117 & 53 & 0,5 \\
\hline -Autonomous decision - Certification & Auton_Cert & 0,1 & 117 & 3 & 0,16 \\
\hline -Autonomous decision - Traceability & Auton_Trace & 0,1 & 117 & 6 & 0,22 \\
\hline \multicolumn{6}{|l|}{ Partner directions } \\
\hline - Partner directions - HACCP & Partndir_HACCP & 0,1 & 117 & 5 & 0,2 \\
\hline - Partner directions - Certification & Partndir_Cert & 0,1 & 117 & 1 & 0,09 \\
\hline - Partner directions - Traceability & Partndir_Trace & 0,1 & 117 & 1 & 0,09 \\
\hline \multicolumn{6}{|l|}{ Control variables } \\
\hline \multicolumn{6}{|l|}{ Beliefs } \\
\hline $\begin{array}{l}\text { To ensure food safety is a law duty } \\
\text { - I completely disagree }\end{array}$ & Law & -2 & 117 & 1 & 0.60 \\
\hline - I disagree & & $\begin{array}{l}-2 \\
-1\end{array}$ & 111 & $\begin{array}{l}1 \\
2\end{array}$ & 0,00 \\
\hline - I do not know & & 0 & & 1 & \\
\hline - I agree & & 1 & & 6 & \\
\hline - I completely agree & & 2 & & 107 & \\
\hline $\begin{array}{l}\text { To ensure food safety increases the number } \\
\text { of clients and the sales }\end{array}$ & Custom & & & & \\
\hline - I completely disagree & & -2 & 117 & 7 & 1,20 \\
\hline - I disagree & & -1 & & 11 & \\
\hline - I do not know & & 0 & & 4 & \\
\hline •I agree & & 1 & & 39 & \\
\hline - I completely agree & & 2 & & 56 & \\
\hline $\begin{array}{l}\text { To ensure food safety increases the prices } \\
\text { of the products }\end{array}$ & Price & & & & \\
\hline - I completely disagree & & -2 & 117 & 24 & 1,39 \\
\hline - I disagree & & -1 & & 24 & \\
\hline • I do not know & & 0 & & 12 & \\
\hline - I agree & & 1 & & 42 & \\
\hline - I completely agree & & 2 & & 15 & \\
\hline \multicolumn{6}{|l|}{ Sources of information } \\
\hline - Technicians & Tech & 0,1 & 115 & 94 & 0,39 \\
\hline - Public Health officials & Asl & 0,1 & 115 & 100 & 0,34 \\
\hline - Advertsing & Publ & 0,1 & 115 & 49 & 0,50 \\
\hline - Other enterpreneurs & Enterpr & 0,1 & 115 & 14 & 0,33 \\
\hline $\begin{array}{l}\text { - Number of high level managers, as } \\
\text { index of the capability to cope with } \\
\text { technological uncertainty a }\end{array}$ & Ndir & & 114 & 21,8 & 25,6 \\
\hline $\begin{array}{l}\text { - Year of experience of the top manager, } \\
\text { as index of the capability to cope with } \\
\text { technological uncertainty a }\end{array}$ & Exper & & 117 & 20876 & 23976 \\
\hline $\begin{array}{l}\text { - Volume of sales as an index of the size } \\
\text { of the firm a }\end{array}$ & Sales & & 117 & 54,3 & 15,83 \\
\hline
\end{tabular}

Source: the authors. 
For the purpose of the empirical analysis presented, three types of investment for each food safety system are considered: a) physical resources, b) human resources and c) additional management costs generated by internal organizational activities. The variables used in the analysis are presented in Table 1.

Moreover, we considered the following control variables whose purpose is to take into account general factors potentially influencing the dependent variables.

The Beliefs variable captures the subjective evaluation of the motivations to invest (Aoki, 2011) and accounts for the cognitive perspective of the decision-making process. Drivers of decisions to invest reflect the estimation of the respondents. According to the literature, three prominent beliefs are identified: a) compliance with the law (Law) (Loader and Hobbs, 1999); b) expectations regarding profitability in terms of the number of clients and sales (Custom) (Zhou et al., 2012); and 3) expectations for premium pricing in relation to the degree of safety (Price) (Loader and Hobbs, 1999; Trienekens and Zuurbier, 2008; Fares and Rouviere, 2010).

Each Source of information is believed to have a specific effect. In this context, Technicians are associated with chain relationships, as the connection between, for example, poultry companies and farmers under contract is normally guaranteed by a company's technicians' network, as described by Martino and Polinori (2011). It is expected that this variable strengthens the role of Partndir in explaining investment decisions. Likewise, Asl - which captures the information provided by public health agencies - is expected to be associated with Law. Publ is used to prove the influence of free sources of information, creating zero cost information on the adoption decision, and Enterpr accounts for information from other entrepreneurs. The information considered concerns technology and related risks. A positive effect of this variable would indicate that the source influences the probability of investing. Control variables are taken into account that may influence the decision to invest but are not related to the decision to allocate the decision right to invest. Both the control variables Ndir and Exper are intended to account for the ability of manager-based tacit knowledge to cope with technological uncertainty and to subsequently invest.

Scholars have underlined the role of the size of a business in adopting food safety systems (Loader and Hobbs, 1999; Trienekens and Zuurbier, 2008; DeLind and Howard 2008). Therefore, the variable Sales is introduced in order to account for the influence of scale.

\subsection{Empirical results}

\subsubsection{Analysis of the GEE model results}

A total of 177 questionnaires were completed and returned (response rate: 8.89\%). Among these questionnaires, 117 were used in the present study. The remaining questionnaires were incomplete and lacked some of the required variables.

The sample is characterized by a small presence of skilled workers, technicians and managers. $49.7 \%$ of the top managers are more than 50 years old. A small percentage of managers with university degrees possess a large amount of work experience. Of the establishments investigated, $26.6 \%$ engage in specialized production and $18.6 \%$ in production and trade, whereas $54 \%$ specialize in trading activities.

Table 2 summarizes the distribution of drivers resulting from the questionnaires. Legislative pressure is found to be the most influential driver of investment in HACCP and Traceability, and it also plays an important role in Certification. Autonomy and the direction of partners are important investment drivers for Certification.

Table 2 - Distribution of drivers in safety systems.

\begin{tabular}{|l|c|c|c|}
\hline \multicolumn{1}{|c|}{ System } & Law & $\begin{array}{c}\text { Full } \\
\text { freedom }\end{array}$ & $\begin{array}{c}\text { Partner } \\
\text { directions }\end{array}$ \\
\hline HACCP & 72.7 & 25.0 & 2.3 \\
\hline Certification & 22.5 & 69.0 & 8.5 \\
\hline Traceability & 57.4 & 39.0 & 3.7 \\
\hline
\end{tabular}

Source: the authors.

Table 3 summarizes the results of the GEE estimates (considering all three types of investment, there are three data lines for each respondent). Therefore, the data set for the estimation 
Table 3 - Generalized equations estimates (Agresti, Liu, 2001).

\begin{tabular}{|c|c|c|c|c|c|c|}
\hline \multirow[b]{2}{*}{ Variables } & \multicolumn{3}{|c|}{ Parameter estimated } & \multicolumn{3}{|c|}{ Marginal effects } \\
\hline & INV НАСCP & INV Cert & INV Trace & INV НАCCP & INV Cert & INV Trace \\
\hline Law_HACCP & $\begin{array}{c}0.574 * * \\
(2.51)\end{array}$ & & & $\begin{array}{c}0.137^{* *} \\
(2.63)\end{array}$ & & \\
\hline Auton_HACCP & $\begin{array}{c}0.0633301 \\
(0.30)\end{array}$ & & & $\begin{array}{l}0.0156 \\
(0.30)\end{array}$ & & \\
\hline Partndir_HACCP & $\begin{array}{c}0.7771158 \\
(1.45)\end{array}$ & & & $\begin{array}{c}0.19 \\
(1.52)\end{array}$ & & \\
\hline Law_Cert & & $\begin{array}{c}1.687^{* * *} \\
(4.25)\end{array}$ & & & $\begin{array}{c}0.385^{* * *} \\
(4.32)\end{array}$ & \\
\hline Auton_Cert & & $\begin{array}{c}2.065^{* * *} \\
(6.84)\end{array}$ & & & $\begin{array}{c}0.413 * * * \\
(7.60)\end{array}$ & \\
\hline Partindir_Cert & & $\begin{array}{l}1.111^{*} \\
(1.67)\end{array}$ & & & $\begin{array}{l}0.257 \\
(1.57)\end{array}$ & \\
\hline Law_Trace & & & $\begin{array}{c}0.493^{* *} \\
(2.44)\end{array}$ & & & $\begin{array}{c}0.119^{* *} \\
(2.49)\end{array}$ \\
\hline Auton_Trace & & & $\begin{array}{c}0.593 * * * \\
(2.91)\end{array}$ & & & $\begin{array}{c}0.145^{* * *} \\
(2.94)\end{array}$ \\
\hline Partndir_Trace & & & $\begin{array}{l}-0.417 \\
-(0.89)\end{array}$ & & & $\begin{array}{c}0.098 \\
-(0.94)\end{array}$ \\
\hline Law & $\begin{array}{l}-0.224^{*} \\
-(1.76)\end{array}$ & $\begin{array}{l}-0.294 \\
-(1.54)\end{array}$ & $\begin{array}{c}-0.467 * * * \\
-(3.69)\end{array}$ & $\begin{array}{l}-0.55^{*} \\
(-1.77)\end{array}$ & $\begin{array}{l}-0.058 \\
-(1.56)\end{array}$ & $\begin{array}{c}0.115 * * * \\
-(3.71)\end{array}$ \\
\hline Custom & $\begin{array}{c}-0.011798 \\
-(0.13)\end{array}$ & $\begin{array}{l}-0.09 \\
-(0.66)\end{array}$ & $\begin{array}{l}-0.043 \\
-(0.47)\end{array}$ & $\begin{array}{l}-0.0029 \\
-(0.13)\end{array}$ & $\begin{array}{c}-0.18 \\
-(0.66)\end{array}$ & $\begin{array}{c}0.01 \\
-(0.47)\end{array}$ \\
\hline Price & $\begin{array}{c}-0.059639 \\
-(0.74)\end{array}$ & $\begin{array}{l}-0.024 \\
-(0.20)\end{array}$ & $\begin{array}{l}0.005 \\
(0.06)\end{array}$ & $\begin{array}{l}-0.014 \\
-(0.74)\end{array}$ & $\begin{array}{l}-0.005 \\
-(0.20)\end{array}$ & $\begin{array}{c}0.0013 \\
(0.06)\end{array}$ \\
\hline Tech & $\begin{array}{c}0.0230853 \\
(0.11)\end{array}$ & $\begin{array}{c}-0.39 \\
-(1.37)\end{array}$ & $\begin{array}{c}-0.24 \\
-(1.22)\end{array}$ & $\begin{array}{c}0.0056 \\
(0.11)\end{array}$ & $\begin{array}{l}-0.081 \\
-(1.32)\end{array}$ & $\begin{array}{l}-0.059 \\
-(1.22)\end{array}$ \\
\hline Asl & $\begin{array}{c}0.1861495 \\
\quad(0.72)\end{array}$ & $\begin{array}{l}0.121 \\
(0.31)\end{array}$ & $\begin{array}{l}0.166 \\
(0.60)\end{array}$ & $\begin{array}{c}0.0456 \\
(0.72)\end{array}$ & $\begin{array}{l}0.023 \\
(0.32)\end{array}$ & $\begin{array}{c}0.04 \\
(0.61)\end{array}$ \\
\hline Publ & $\begin{array}{c}0.1399031 \\
(0.83)\end{array}$ & $\begin{array}{l}-0.088 \\
-(0.35)\end{array}$ & $\begin{array}{l}0.296^{* *} \\
(1.72)\end{array}$ & $\begin{array}{c}0.0346 \\
(0.83)\end{array}$ & $\begin{array}{l}-0.017 \\
-(0.35)\end{array}$ & $\begin{array}{c}0.073 * \\
(1.73)\end{array}$ \\
\hline Entepr & -0.103416 & $\begin{array}{l}-0.285 \\
-(0.73)\end{array}$ & $\begin{array}{l}0.146 \\
(0.56)\end{array}$ & $\begin{array}{l}-0.0254 \\
-(0.41)\end{array}$ & $\begin{array}{l}-0.053 \\
-(0.77)\end{array}$ & $\begin{array}{l}0.036 \\
(0.56)\end{array}$ \\
\hline Ndir & $\begin{array}{c}-0.009949 \\
-(2.80)\end{array}$ & $\begin{array}{l}-0.007 \\
-(1.21)\end{array}$ & $\begin{array}{c}-0.007^{* *} \\
-(1.99)\end{array}$ & $\begin{array}{c}-0.0024 * * * \\
-(2.81)\end{array}$ & $\begin{array}{l}-0.001 \\
-(1.22)\end{array}$ & $\begin{array}{c}-0.0018^{* *} \\
-(1.99)\end{array}$ \\
\hline Sales & $\begin{array}{c}-3.39 \mathrm{E}-06 \\
-(0.89)\end{array}$ & $\begin{array}{c}0 \\
-(0.77)\end{array}$ & $\begin{array}{c}0 \\
-(0.51)\end{array}$ & $\begin{array}{l}-8,00 \mathrm{E}-7 \\
-(0.89)\end{array}$ & $\begin{array}{c}-0.0000009 \\
-(0.77)\end{array}$ & $\begin{array}{c}-7,00 \mathrm{E}-8 \\
-(0.51)\end{array}$ \\
\hline Exper & $\begin{array}{c}-0.004293 \\
-(0.89)\end{array}$ & $\begin{array}{l}-0.018 \\
-(2.51)\end{array}$ & $\begin{array}{l}0.003 \\
(0.63)\end{array}$ & $\begin{array}{c}-0.00106 \\
-(0.89)\end{array}$ & $\begin{array}{c}-0.0035^{* *} \\
-(2.54)\end{array}$ & $\begin{array}{l}0.0008 \\
(0.63)\end{array}$ \\
\hline Number of obs & 336 & 336 & 336 & & & \\
\hline Number of groups & 112 & 112 & 112 & & & \\
\hline Obs per group: min & 3 & 3 & 3 & & & \\
\hline Avg & 3 & 3 & 3 & & & \\
\hline Max & 3 & 3 & 3 & & & \\
\hline Wald chi2(13) & 27.27 & 88.12 & 34.7 & & & \\
\hline Prob > chi2 & 0.0114 & 0.0000 & 0.0009 & & & \\
\hline
\end{tabular}

$t$ statistics in parentheses $* p<0.05, * * p<0.01$, $* * * p<0.001$

Source: the authors. 
has $3 \times 117=351$ observations). The effect of each variable on the probability of investment is measured by the average marginal effect.

The coefficients of Law_HACCP and Law are statistically significant, indicating that legislative pressure determines the decision to invest in the sample. The AME indicates that the legislation inducement yields a $13.7 \%$ increase in the probability of investing in HACCP systems. Notably, Law beliefs are not aligned, on average, with the influence declared (AME $=-55.0 \%$ ), and the influence of Ndir is slightly negative. This evidence suggests that even though the respondents perceive the influence of legal pressure as weaker than that of other drivers, they believe that food safety is not a legal obligation.

In the case of Certification, all three drivers explain the probability of investing. Law Cert increases the probability of investing by $38.5 \%$, whereas the effect of Autonomy is $41.7 \%$. The variable Exper has a small negative effect. Investments in Traceability are explained by Law
Trace and Auton_Trace, with effects of $11.9 \%$ and $14.5 \%$, respectively. $L a w$ and $P u b l$ have positive effects, whereas $N d i r$ has a negative influence.

In considering the results of the GEE estimation, the driver Law influences the decision to invest in HACCP and Traceability as expected, and Autonomy has the expected influence on Certification. The allocation of the decision right of partners contributes to explaining decisions related only to Certification. Law also has a strong influence on Certification. This unexpected evidence may be explained by the organic suppliers or exporters potentially included in the sample. The role of contract freedom in the Traceability system may be explained by investment decisions that are not directly influenced by the law.

\subsubsection{Interlinkage between regulation and the negotiation of parties}

The bivariate probit models for HACCP investments (PR HACCP-HR HACCP, PR HACCP-CO_HACCP, HR_HACCP-CO_HACCP)

Table 4 - Probit estimate by food safety management systems.

\begin{tabular}{|c|c|c|c|c|c|c|c|c|c|}
\hline & \multicolumn{3}{|c|}{ HACCP } & \multicolumn{3}{|c|}{ Certification } & \multicolumn{3}{|c|}{ Traceability } \\
\hline & $P R \_H A C C P$ & HR_HACC & CO_HACCP & PR_Cert & HR_Cert & CO_Cert & $P R \_$Trace & HR_Trace & CO_Trace \\
\hline Law_HACCP & $1.037 * * *$ & $0.727 * * *$ & 0.276 & & & & & & \\
\hline Auton_HACCP & 0.211 & 0.0451 & -0.202 & & & & & & \\
\hline Partndir_HACCP & 8.117 & -8.669 & 10.55 & & & & & & \\
\hline Law_Cert & & & & $12.184 * * *$ & $-6.220 * * *$ & $1.102 * *$ & & & \\
\hline Auton_Cert & & & & $6.627 * * *$ & $0.833^{* * *}$ & $0.564 * *$ & & & \\
\hline Partndir_Cert & & & & $6.6753^{* * *}$ & $0.613 * * *$ & $1.046^{*}$ & & & \\
\hline Law_Trace & & & & & & & $0.786^{*}$ & $0.437 * * *$ & -3.745 \\
\hline Auton_Trace & & & & & & & 0.163 & $0.442 * * *$ & 0.0542 \\
\hline Partndir_Trace & & & & & & & 8.460 & $-4915 * * *$ & -4.294 \\
\hline cons & & & $0.634 * * *$ & $-5.822 * * *$ & $-1.518 * * *$ & & $-1.285^{* *}$ & & 0.962 \\
\hline Law & -0.311 & 0.241 & -0.0631 & 0.191 & 0.0703 & 0.217 & -0.0892 & -0.214 & 0.0558 \\
\hline Custom & $-0.315^{*}$ & -0.136 & $-0.452 * * *$ & -0.232 & -0.171 & -0.184 & $*-0.425 * *$ & -0.174 & $-0.392 * *$ \\
\hline Price & $0.266^{*}$ & 0.0902 & $0.302 * *$ & $0.214^{*}$ & 0.244 & 0.197 & 0.222 & 0.102 & $0.248^{*}$ \\
\hline Tech & 0.0771 & 0.251 & -0.0694 & 0.339 & 0.452 & 0.563 & -0.0646 & -0.111 & 0.367 \\
\hline Asl & 0.709 & 0.992 & 0.37 & $1.049 * *$ & $1.303^{* * *}$ & 1.050 & 0.494 & $0.641^{*}$ & 0.896 \\
\hline Publ & 0.0868 & $0.364 *$ & 0.0932 & 0.134 & 0.0376 & -0.0759 & -0.0163 & 0.183 & 0.218 \\
\hline Enterpr & 0.349 & 0.423 & $0.676^{*}$ & 0.348 & 0.372 & $0.672 *$ & $0.618^{*}$ & $0.661 * * *$ & $0.649 *$ \\
\hline Ndir & -0.0107 & -0.00473 & -0.00281 & -0.00878 & $-0.0125^{*}$ & -0.00539 & -0.0052 & $-0.009 * * *$ & -0.0057 \\
\hline Sales & -0.0000051 & $-1.51 \mathrm{E}-06$ & $-2.71 \mathrm{E}-07$ & $-7.32 \mathrm{E}-07$ & $-5.54 \mathrm{E}-06$ & $-2.38 \mathrm{E}-06$ & $-2.72 \mathrm{E}-06$ & $-7.39-06^{* *}$ & $-2.74 \mathrm{E}-06$ \\
\hline Exper & 0.000328 & 0.00744 & -0.00374 & $0.0131^{* *}$ & 0.0152 & 0.00933 & -0.00292 & -0.0026 & 0.098 \\
\hline _cons & & $-2.398^{*}$ & & $-2.324^{*}$ & $-2.568 * *$ & $-2.554^{*}$ & & & -1.840 \\
\hline$\overline{\mathrm{N}}$ & 112 & 112 & 112 & 112 & 112 & 112 & 112 & 112 & 112 \\
\hline Wald $c^{2}$ & 19.03 & $5.13+\mathrm{e} 12$ & 1989.77 & . & $1.6+\mathrm{e} 11$ & 19.97 & 6.82 & 112860.46 & 0.8 \\
\hline Prob $>c^{2}$ & 0.0003 & 0.0000 & 0.0000 & . & 0.0000 & 0.0020 & 0.0800 & 0.0000 & 0.8500 \\
\hline $\mathrm{r}$ & -0.793 & -1.000 & -1.000 & -1.000 & 1.000 & 1.000 & 1.000 & -1.000 & -0.696 \\
\hline $\mathrm{c}^{2}$ & 4.17 & 0.19 & 5.42 & 165.55 & 6.67 & 40.53 & 8.55 & 7.86 & 0.5 \\
\hline Prob $>c^{2}$ & 0.0410 & 0.6700 & 0.0200 & 0.0000 & 0.0098 & 0.0000 & 0.0035 & 0.0050 & 0.4770 \\
\hline
\end{tabular}

$t$ statistics in parentheses; $* p<0.05$, ** $p<0.01$, *** $p<0.001$

Source: the authors. 
have large and statistically significant correlation between the residuals of the pairs of equations. We can then check whether or not the coefficient of the investment drivers turns out to be significant in the bivariate model with respect to the univariate case. Comparing the bivariate and the univariate cases, we point out that in the former the variable Law has a greater significance in the models PR_HACCP-HR_HACCP and PR_HACCP-CO_HACCP and that the variable PARTNEdIR has greater statistical significance - compared to the univariate case - in the models PR_HACCP-CO_HACCP and HR_HACCP-CO_HACCP. We therefore conclude that in the HACCP systems the interlinkage between the investment drivers is articulated in terms of complementarity between the physical and the additional costs investments calling for tasks to be jointly performed by the transaction partners.

In the model for Certification investments (PR_Cert-HR_Cert, PR_Cert -CO_Cert, HR Cert -CO_ Cert) the variables Law_Cert (for physical resources) and Partndir_Cert (human resources and additional costs) are statistically significant while they are not in the univariate model. Therefore, we submit that the complementarity between these types of investments also support the interlinkage between the investment drivers.

In the models for traceability we find correlation between the residuals only for physical resources and additional costs. For the latter, we found an increase of statistical significance for both Legal duties and Partner directions, indicating that in this case the complementarity between the investments induces a linkage between the drivers.

In general, we interpret the complementarity between the types of investment in technological terms. For example, it is reasonable to expect that investment in physical resources may requires additional costs of management or that all the systems require enhanced human skills.

\section{Discussion}

The basic idea was to identify the role of the main causes of the investment decisions within an organizational perspective. Legal decision and private strategies create a complex network of rules and incentives aimed at achieving an enhanced degree of food safety (Garcia Martinez et al., 2007; Benmehaia and Brabez, 2018); therefore, each driver can influence a specific type of investment. The main result of the study is that, according to theory, the allocation of the decision right to invest in food safety explains the patterns of investment decisions observed.

The second aspect considered is the prevalence of such effects. In the case of HACCP, the driver related to the legal obligation for both physical resources and human resources. In Certification, free choice and partner requests drivers are prevalent. Finally, for the traceability system, the drivers related to the legal obligation and free choices exert similar influences on physical resources, whereas the legal obligation is prevalent in human resources-type investments. The results reveal a large coefficient for public health officials in the case of persistent increased costs. This finding indicates that public regulation induces activities that necessitate increased costs. A number of studies have found similar results. For example, Henson and Hooker (2001, p. 11) state that compliance with regulation affects business performance according to the capabilities and resources of each company, and that regulation tends to impose additional costs on businesses. This point is also underlined by Loader and Hobbs (1999), and Mensah and Julien (2011). In the case of investment in physical resources and human resources for certification investment, the results of this study are compatible with the predictions of Fares and Rouviere (2010): the greater influence of the law, is associated with a greater joint influence of the drivers free choice and partner directions.

The AMEs of Size are small and reveal contrasting signs in the model. A possible interpretation is that the allocation of decision rights to invest allows companies to overcome problems related to size. This result contradicts studies that have underlined the difference between large and small companies in complying with regulations and the adoption of standards (Loader and Hobbs, 1999; Trienekens and Zuurbier, 2008; Mensah and Julien, 2011), and that emphasize the increase in transaction costs at the 
individual level as a result of regulation, regardless of business size. These results suggest that organizational decisions, such as the allocation of decision rights, may sustain agents in coping with the additional production and managerial costs generated by such regulation.

The results are similar to the results of studies emphasizing that food safety outcomes depend on the decisions of several actors (Hutter and Jones 2007; Heyder et al., 2012; Cafaggi and Iamiceli, 2014).

The evidence of the research indicates that the allocation of decision rights has clear explanatory power for investment choices. As a consequence, it is necessary to underline the importance of the organizational dimensions in the definition of the business model. The evidence gathered is compatible with economic theory predicting that the line of association between law and free will, in the combination of private and public regulation, is related to strategies used to cope with uncertainty that have both scientific (Majone, 2010) and technological origins. The allocation of the decision right to invest, allows agents and the regulator to cope with the information issue arising both between the transacting parties and between private and public agents. However, the allocation of decision rights acts as a means of coping with the uncertainty that accompanies the provision of safe food to end consumers (Fabinyi and Liu, 2014; Lockie, 2006). From this perspective, regulatory interventions may be more effective if the business models are defined connecting the principles of sustainability with the efficiency principles leading the allocation of decision rights (Ménard, 2013). The research points out that the way the sustainability strategies are implemented through operational business models is not only subject to the necessity of meeting the market requirements, but also to the necessity of efficiently combining the law and food chain coordination commitments (Ménard, 2013).

\section{Final remarks}

This study is focused on inducements to invest resulting from the necessity of complying with the law (public regulation), from an enter- prise's free will, or from a business partner's request (private regulation). The role of these drivers was analyzed in selected food safety systems and for different types of investments, within the theoretical framework of a sustainable business model. The results indicate that the analysis of decision rights is meaningful in investigating how public and private regulations are related in assuring food safety for consumers. On the one hand, the allocation of decision rights appears to be the organizational response of public and private agents. On the other hand, coordination among the agents appears to be an important element constituting the sustainable food business model. The main limitation of this study is that the questionnaires did not seek information regarding the allocation of decision rights to collective bodies such as producers' associations, which play a role in many of the systems considered. This information is excluded from the study for two reasons. First, these collective bodies had a limited and unsystematic level of importance at the time of this investigation. Second, the influence of these associations largely determined the design of specific chain relationships whose outcomes were captured by the allocation of decision rights among the transacting parties. Information regarding the role of these collective bodies will become relevant in the near future in the context of expected changes in the EU's agricultural policy. Additionally, because the relationship between investment drivers may entail both substitution and complementarity, further developments in this area of study will analyze these aspects in greater detail. Knowledge of the patterns of the influence of public/ private co-regulation on investments in food safety systems may contribute to the designing of public and private policies aimed at increasing product safety and sustainability.

\section{References}

Agresti A., Liu I., 2001. Strategies for modeling a categorical variable allowing multiple category choices. Sociological Methods \& Research, 29(4): 403-434. 
Aoki M., 2011. Institutions as cognitive media between strategic interactions and individual beliefs. Journal of Economic Behavior \& Organization, 79(1-2): 20-34.

Banterle A., Stranieri S., 2008. The consequences of voluntary traceability system for supply chain relationships. An application of transaction cost economics. Food Policy, 33(6): 560-569.

Benmehaia M.A., Brabez F., 2018. Vertical Relationships and Food Supply Chain Coordination: The Case of Processing Tomato Sector in Algeria. New Medit, 17(2): 3-14.

Beske P., Koplin J., Seuring S., 2008. The use of environmental and social standards by German first-tier suppliers of the Volkswagen AG. Corporate Social Responsibility and Environmental Management, 15(2): 63-75.

Buvik A., Grønhaug K., (2000). Inter-firm dependence, environmental uncertainty and vertical co-ordination in industrial buyer-seller relationships. Omega, 28(4): 445-454.

Cafaggi F., Iamiceli P., 2014. Supply chains, contractual governance and certification regimes. European journal of law and economics, 37(1): 131-173.

Cassiman B., Veugelers R., 2006. In search of complementarity in innovation strategy: Internal R\&D and external knowledge acquisition. Management science, 52(1): 68-82.

Coase R., 1959. The Federal Communication Commission. Journal of Law and Economics, 2: 1-40.

Crespi J.M., Marette S.P., 2001. How should food safety certification be financed? American journal of agricultural economics, 83(4): 852-861.

DeLind L.B., Howard P.H., 2008. Safe at any scale? Food scares, food regulation, and scaled alternatives. Agriculture and Human Values, 25(3): 301317.

Dosman D.M., Adamowicz W.L., Hrudey S.E., 2001. Socioeconomic determinants of health-and food safety-related risk perceptions. Risk analysis, 21(2): 307-318.

Elbasha E.H., Riggs T.L., 2003. The effects of information on producer and consumer incentives to undertake food safety efforts: A theoretical model and policy implications. Agribusiness: An International Journal, 19(1): 29-42.

European Commission, 2002. Regulation (EC) No 178/2002, article 3, 15.

Fabinyi M., Liu N., 2014. Seafood banquets in Beijing: consumer perspectives and implications for environmental sustainability. Conservation and Society, 12(2): 218-228.
Fares A., Rouviere E., 2010. The implementation mechanisms of voluntary food safety systems. Food Policy, 35(5): 412-418.

Galvez J.F., Mejuto J.C., Simal-Gandara J., 2018. Future challenges on the use of blockchain for food traceability analysis. TrAC Trends in Analytical Chemistry, 107: 222-232.

Garcia Martinez M., Fearne A., Caswell J.A., Henson S., 2007. Co-regulation as a possible model for food safety governance: Opportunities for publicprivate partnerships. Food Policy, 32(3): 299-314.

Gil M.I., Selma M.V., Suslow T., Jacxsens L., Uyttendaele M., Allende A., 2015. Pre-and postharvest preventive measures and intervention strategies to control microbial food safety hazards of fresh leafy vegetables. Critical reviews in food science and nutrition, 55(4): 453-468.

Hammoudi A., Hoffmann R., Surry Y., 2009. Food safety standards and agri-food supply chains: an introductory overview. European Review of Agricultural Economics, 36(4): 469-478.

Henson S., Hooker N.H., 2001. Private sector management of food safety: public regulation and the role of private controls. The International Food and Agribusiness Management Review, 4(1): 7-17.

Herath D., Henson S., 2010. Barriers to HACCP implementation: evidence from the food processing sector in Ontario, Canada. Agribusiness, 26(2): 265-279.

Heyder M., Theuvsen L., Hollmann-Hespos T., 2012. Investments in tracking and tracing systems in the food industry: a PLS analysis. Food Policy, 37(1): 102-113.

Hobbs J.E., 2004. Information asymmetry and the role of traceability systems. Agribusiness: An International Journal, 20(4): 397-415.

Hutter B.M., Jones C.J., 2007. From government to governance: External influences on business risk management. Regulation \& Governance, 1(1): 27-45.

Jacxsens L., Kirezieva K., Luning P.A., Ingelrham J., Diricks H., Uyttendaele M., 2015. Measuring microbial food safety output and comparing self-checking systems of food business operators in Belgium. Food Control, 49: 59-69.

Karaman A.D., Cobanoglu F., Tunalioglu R., Ova G., 2012. Barriers and benefits of the implementation of food safety management systems among the Turkish dairy industry: A case study. Food Control, 25(2): 732-739.

Lafontaine F., Slade M.E., 2013. Inter-firm Contracts. In: Gibbons R., Roberts J. (eds.), The handbook of Organizational Economics. Pricenton, Oxford: Princeton University Press, pp. 958-1013. 
Leal M.C., Pimentel T., Ricardo F., Rosa R., Calado R., 2015. Seafood traceability: current needs, available tools, and biotechnological challenges for origin certification. Trends in biotechnology, 33(6): 331-336.

Loader R., Hobbs J.E., 1999. Strategic responses to food safety legislation. Food policy, 24(6): 685706.

Lockie S., 2006. Capturing the sustainability agenda: Organic food and media disclosures. Agr. Hum. Values., 23(3): 313-323.

Lupien J.R., 2005. Food quality and safety: traceability and labeling. Critical reviews in food science and nutrition, 45(2): 119-123.

Majone G., 2010. Foundations of risk regulation: Science, decision-making, policy learning and institutional reform. European Journal of Risk Regulation, 1(1): 5-19.

Malorgio G., Biondi B., Perito M.A., 2016. Strategic behaviour of Italian fruit and vegetables importers from South Mediterranean Countries faced with food safety standards. New Medit, 15(3): 29-36.

Martino G., Bavorovà M., 2014. An Analysis of Food Safety Private Investments Drivers in the Italian Meat Sector. Proceedings in Food System Dynamics, 229-251.

Martino G., Perugini C., 2006. Hybrid forms in food safety supply. In: Bijman J., Omta O., Trinekens J., Wijnands J., Wubben E. (eds.), International Agrifood Chains and Networks: Management and Organizations. Wageningen: Wageningen Academic Publishers, pp. 287-301.

Martino G., Polinori P., 2011. Networks and organisational learning: evidence from broiler production. British Food Journal, 113(7): 871-885.

McMichael A.J., Powles J.W., Butler C.D., Uauy R., 2007. Food, livestock production, energy, climate change, and health. Lancet, 370(9594): 1253-1263.

Ménard C., 2013. Hybrid modes of organization. Alliance, Joint Ventures, Networks and Other Strange Animals. In: Gibbons R., Roberts J. (eds.), The handbook of Organizational Economics. Pricenton, Oxford: Princeton University Press, pp. 1066-1105.

Ménard C., 2018. Organization and governance in the agrifood sector: How can we capture their variety? Agribusiness, 34(1): 142-160.

Mensah L.D., Julien D., 2011. Implementation of food safety management systems in the UK. Food Control, 22(8): 1216-1225.
Milgrom P., Roberts J., 1990. The economics of modern manufacturing: Technology, strategy, and organization. American economic review, 80(3): 511-528.

Nanyunja J., Jacxsens L., Kirezieva K., Kaaya A.N., Uyttendaele M., Luning P.A., 2015. Assessing the status of food safety management systems for fresh produce production in East Africa: evidence from certified green bean farms in Kenya and noncertified hot pepper farms in Uganda. Journal of food protection, 78(6): 1081-1089.

Psomas E.L., Kafetzopoulos D.P., 2015. HACCP effectiveness between ISO 22000 certified and non-certified dairy companies. Food Control, 53: 134-139.

Quetier F., Marty P., Lepart J., 2005. Farmers' management strategies and land use in an agropastoral landscape: roquefort cheese production rules as a driver of change. Agricultural Systems, 84(2): 171193.

Regattieri A., Gamberi M., Manzini R., 2007. Traceability of food products: General framework and experimental evidence. Journal of food engineering, 81(2): 347-356.

Rott P. (ed.), 2019. Certification - Trust, Accountability, Liability. Cham: Springer Nature.

Segerson K., 1999. Mandatory versus voluntary approaches to food safety. Agribusiness, 15(1): 53-70.

Tian F., 2017. A supply chain traceability system for food safety based on HACCP, blockchain \& Internet of things. In: 2017 International Conference on Service Systems and Service Management, Dalian, pp. 1-6, doi: 10.1109/ICSSSM.2017.7996119.

Tompkin R.B., 1990. The use of HACCP in the production of meat and poultry products. Journal of food protection, 53(9): 795-803.

Trienekens J., Zuurbier P., 2008. Quality and safety standards in the food industry, developments and challenges. International Journal of Production Economics, 113(1): 107-122.

Wilcock A., Ball B., Fajumo A., 2011. Effective implementation of food safety initiatives: managers', food safety coordinators' and production workers' perspectives. Food Control, 22(1): 27-33.

Williamson O.E., 1985. The Economic Institutions of Capitalism. NewYork: FreePress.

Zhou G., Zhang W., Xu X., 2012. China's meat industry revolution: Challenges and opportunities for the future. Meat science, 92(3): 188-196. 